\title{
KRAJOBRAZ I KRAJOBRAZY W LIRYCE CZESŁAWA MIŁOSZA, FRIEDRICHA HÖLDERLINA I JOHANNESA BOBROWSKIEGO ${ }^{1}$
}

\author{
ROLF FIEGUTH ${ }^{2}$ \\ (Fribourg)
}

\begin{abstract}
Słowa kluczowe: liryka krajobrazowa, tradycja antyczna i pośredniowieczna, Europa sarmacka i zachodnia, II wojna światowa, sposoby wierszowania
\end{abstract}

Keywords: landscape poetry, ancient and post medieval traditions, Sarmatian and Western Europe, World War II, versification styles

\begin{abstract}
Abstrakt: Rolf Fieguh, KRAJOBRAZ I KRAJOBRAZY W LIRYCE CZESŁAWA MIŁOSZA, FRIEDRICHA HÖLDERLINA I JOHANNESA BOBROWSKIEGO. „PORÓWNANIA” 10, 2012, Vol. X, s. 87-108, ISSN 1733-165X. Autor omawia szereg wierszy krajobrazowych Cz. Miłosza z różnych okresów jego twórczości, porównując je z wybranymi utworami wirtemberczyka, F. Hölderlina oraz tylżyckiego poety J. Bobrowskiego. Każdy $\mathrm{z}$ nich stale wraca $\mathrm{w}$ poezji do krajobrazu dzieciństwa, utraconego nie tylko za sprawą wojny (Miłosz i Bobrowski), ale też przez egzystencjalne wyobcowanie (Hölderlin) i który przyświeca im jako znak ojczyzny niebiańskiej. Hölderlina, Miłosza i Bobrowskiego łączy wspólna opozycja do konwencji wierszowania ich epok i ich literatur ojczystych, a dwu ostatnich ponadto wspólna tęsknota do stron nadniemieńskich. Wojenna poezja Miłosza o równinach mazowieckich dziwnie współbrzmi $\mathrm{z}$ „sarmacką" poezją Bobrowskiego, wyrosłą z doświadczeń tego samego okresu. Opisywanie
\end{abstract}

1 Tekst pisany w ścisłym powiązaniu z artykułem Rzeka i rzeki. Liryka krajobrazowa u C. Miłosza, F. Hölderlina i J. Bobrowskiego (przygotowanym na wrocławską konferencję Czestaw Miłosz: duch $i$ władza w "wieku skrajności", 13-15 X 2011) i zawierający niektóre identyczne ustępy. Wybór tematyki 'geograficznej' poprzedziły referaty wygłoszone na gdańskiej konferencji Czesława Miłosza "Pótnocna strona" (21-22 marca 2011 r.), E. Rybicka, Homo geographicus. Mitosza autobio-geo-grafie (rekonesans), w: M. Czermińska, K. Szalewska (red.) Czestawa Miłosza „strona pótnocna”. Gdańsk 2011, 25-37, oraz B. Tarnowska, "W neonowej pustyni”. Obraz amerykańskiej metropolii w twórczości Czestawa Mitosza, ibidem, s. 257-268. Cytuję z wydań: J. Bobrowski, Gesammelte Werke. Hg. v. E. Haufe, Bd. 1-6, Stuttgart 1987 (podając tom i stronę); idem, Wiersze. Wybór, wstęp i przekład E. Wachowiak (Wachowiak i strona); F. Hölderlin, Gedichte. Hg. von J. Schmidt. Frankfurt am Main 1992 (podając stronę); Cz. Miłosz, Wiersze wszystkie. Kraków 2011 (podając stronę).

${ }^{2}$ E-mail Address: rolf@fieguth.ch 
europejskich, a szczególnie amerykańskich krajobrazów przeobraża się u Miłosza w tworzenie krajobrazów mieszanych, amerykańsko-litewskich albo gigantycznie panoramicznych o dobitnych akcentach mitycznych i metafizycznych, które w innych wcieleniach odnaleźć można także u dwu pozostałych poetów. Te paralele i „wspólne miejsca” zawdzięczamy nie tylko eksplicytnym nawiązaniom jednych do drugich, ale również wspólnej tradycji biblijnej, antycznej i pośredniowiecznej oraz wysoce trudnemu, a jednak bliskiemu geograficznie, sąsiedztwu.

Abstract: Rolf Fieguth, LANDSCAPE AND LANDSCAPES IN THE POETRY OF CZESEAW MIŁOSZ, FRIEDRICH HÖLDERLIN AND JOHANNESA BOBROWSKI. „PORÓWNANIA” 10, 2012, Vol. X, s. 87-108, ISSN 1733-165X The author discusses a number of landscape poems, written by C. Miłosz in different periods of his life, and compares them with selected works of the Suabian F. Hölderlin and of the Tilsit poet J. Bobrowski. Each of them returns frequently to the landscape of his childhood, lost not only by the wars (Miłosz and Bobrowski), but also by existential alienation (Hölderlin). Each of them sees in it a symbol of the heavenly homeland. All three are in an opposition to the conventional versification systems of their times and their national literatures, but Miłosz and Bobrowski are moreover linked by their common longing for their native Neman regions. Miłosz's war time poetry on the Mazovian plains shows some striking parallels with Bobrowski's "Sarmatian" poetry stemming from his experiences of the same period. Miłosz's treatment of European and notably American landscapes leads to a creation of mixed, American-Lithuanian or giant panoramic landscapes bearing distinctly mythic and metaphysical accents, which can be found, in a different set up, also in the other poets. These parallels and 'common situations' are not due to some explicit dialogue between them, but to a common Biblical, antique and postmedieval tradition, and also to a highly difficult, but nevertheless geographically close neighbourhood.

Liryka przyrody i liryka krajobrazu są ściśle ze sobą powiązane. Właściwa liryka przyrody, traktująca o natura naturata i natura naturans, ma najczęściej charakter ogólnoludzki, nierzadko metafizyczny czy wprost religijny. Liryka krajobrazowa natomiast często obejmuje dodatkowo małą ojczyznę, kraj oraz fragmenty szerszego świata i z reguły jest nieco bardziej otwarta na echa historii. Porównanie liryki krajobrazowej Czesława Miłosza z twórczością Friedricha Hölderlina i Johannesa Bobrowskiego, które tu proponujemy, mogłoby budzić podejrzenie arbitralności. Hölderlina znał Miłosz raczej powierzchownie, a w kontakcie między Miłoszem a Bobrowskim brak jakichkolwiek wiadomości³. Okazało się jednak, że

${ }^{3}$ Zanim zdecydowałem się w końcu na porównanie Miłosza z Hölderlinem i Bobrowskim, przejrzałem większy krąg poetów niemieckich. Byli to Peter Huchel i Günter Eich jako powojenni wskrzesiciele starszych niemieckich tradycji liryki przyrody i krajobrazu, Paul Celan jako poeta losów żydowskich i autor mniej znanych, a przejmujących wierszy o nadmorskich wybrzeżach, Johannes Bobrowski, Manfred Peter Hein i Günter Grass jako poeci tęsknoty za krajobrazami dzieciństwa nad Szeszupą i Niemnem, Węgorapą czy Wisłą, a od początku też Friedrich Hölderlin, patron nowoczesnej poezji niemieckiej, a także dwudziestowiecznej liryki przyrody i krajobrazu. W końcu decyzja 
wbrew tej okoliczności i mimo poważnych różnic, które ich dzielą, u wszystkich trzech poetów istnieje pewna wspólna tendencja nie tylko do ciągłych powrotów do idealnego krajobrazu dzieciństwa, ale także do dalekiego geograficznego wyjścia poza nie i do tworzenia szerokich poetyckich panoram pejzażowych, a czasem nawet krajobrazów fantastycznych i metafizycznych, w których prawie zawsze niczym głos raju utraconego pobrzmiewa echo krajobrazu dzieciństwa.

Co można powiedzieć o stosunku Miłosza do kultury i literatury niemieckiej? Dla polskiej Litwy XIX wieku kultura ta w swych przejawach nieelitarnych była na ogół po sąsiedzku bliska, codzienna i tego powodu na pewno niezbyt atrakcyjna. Co się zaś tyczy jej wyższych sfer - nauk ścisłych, filozofii, filologii, muzyki, literatury wysokiego autoramentu - mieszały się adoracje i niechęci. Jeszcze w XIX wieku w wielu krajach słowiańskich, zwłaszcza na ziemiach czeskich, w Rosji i w podzielonej Polsce, istniały objawy niechęci nie tylko względem dominacji politycznej Austrii, Prus i później Rzeszy Niemieckiej, ale też względem silnych wpływów niemieckich $\mathrm{w}$ wielu dziedzinach życia intelektualnego. Jest to znane zjawisko i wystarczy w tym miejscu przypomnieć o staraniach czeskich i polskich uczonych w Pradze, Lwowie i Krakowie, by uwolnić się od tych wpływów po ugodzie austriacko-węgierskiej w 1867 r. i dopuścić czeski i polski, jako języki nauczania na uczelniach Czech i Galicji. Rezerwę wobec kultury niemieckiej manifestowali: Mickiewicz w późniejszych latach, Słowacki przez całe życie, czołowi pisarze pozytywizmu, Stefan Żeromski i wielu innych. Należy przyjąć, że niektórzy z wileńskich nauczycieli gimnazjalnych i uniwersyteckich Miłosza podzielali taką postawę. Bez porównania ważniejsza niż poezja niemiecka była dla Miłosza - nie mówiąc o rodzimej polskiej - twórczość antyczna, francuska i anglosaska; nawet poezja rosyjska była mu bliższa ${ }^{4}$. W swej rezerwie wobec niemieckiej poezji i kultury różnił się od nieco starszych poetów jak Tadeusz Peiper (1891), Jarosław Iwaszkiewicz (1894), Julian Tuwim (1894), Julian Przyboś (1901), Mieczysław Jastrun (1903), Józef Czechowicz (1903), Konstanty Ildefons Gałczyński (1905), Stanisław Jerzy Lec (1909). Z drugiej strony warto dziś przypomnieć, że nie mamy prawa nie doceniać wiedzy o kulturze niemieckiej prezentowanej przez wykształconego Polaka w pokoleniu Miłosza, nawet bez znajomości języka niemieckiego. Wiersz Miłosza o Beethovenie pt. Mistrz (481) świadczy o bliskim stosunku do muzyki niemieckiej. Był poeta zainteresowany również niemieckimi teologami i mistykami, w tym Marcinem Lutrem i Jakubem Böhmem. Znaczącą rolę odgrywali dla niego

padła na Bobrowskiego, piewcę „równin sarmackich”, i na jeden z jego wzorców, Hölderlina, poety rodem z Wirtembergii. Grass należy do autorów niemieckich, których Miłosz poznał osobiście i który mógł mu opowiadać o Bobrowskim; zob. Günter Grass, Czesław Miłosz, Wisława Szymborska, Tomas Venclova, Die Zukunft der Erinnerung. Hg. von M. Wäldle. Göttingen 2001.

${ }_{4}^{4}$ Zob. na ten temat mój artykuł Miłosz et les poètes russes de Pouchkine à Pasternak (referat wygłoszony na konferencji Czesław Miłosz, l'Europe et la Russie. Journée d'études 16 septembre 2011, Coppet VD, Suisse; w przygotowaniu). 
filozofowie niemieccy od Immanuela Kanta, Georga Wilhelma Hegla i Karola Marksa do Martina Heideggera i Karola Jaspersa. Możemy przyjąć, że figurował wśród nich również Friedrich Nietzsche, tym bardziej, że był on także poetą - jego Dytyramby dionizyjskie i inne jego wiersze istniały w polskim przekładzie 5 i były na pewno znane Miłoszowi; prawdopodobnie inspirowały go na równi z poezją Słowackiego. Mimo politycznych napięć między Drugą Rzeczpospolitą a Republiką Weimarską w latach po I wojnie światowej powstały prestiżowe i atrakcyjne przekłady z literatury niemieckiej, w tym Johanna Wolfganga Goethego, Rainera Marii Rilkego i Tomasza Manna ${ }^{6}$. Czarodziejska góra i Tonio Kröger należały do głębszych przeżyć lekturowych Miłosza. Oskar Miłosz, wielki mistrz młodego Czesława, był admiratorem Goethego, Schillera i Hölderlina i na pewno nie krył tego przed polskim krewnym ${ }^{7}$. Ale kiedy młodego Czesława Miłosza ciągnęło na zachód, jego celem nie były Niemcy, lecz - naturalnie - Francja, gdzie przebywał zrazu w 1931 r. i następnie w 1934-1935 r. Nie musimy obszernie dowodzić, że rządy nazistowskie w Niemczech, przestępcza niemiecka okupacja Polski i okres tużpowojenny nie mogły przyczynić się do pogłębienia jego związku z kulturą niemiecką. Jednym słowem, nie ma powodów, by przypuszczać, że Miłosz w specjalny sposób reagował na lirykę niemiecką lub prowadził z nią świadomy dialog8. Tym niemniej dają się wykryć pewne paralele i kontrasty, które tłumaczą się prostym faktem, że Polska i Niemcy są mimo wszystko sąsiadami, a bardziej jeszcze tym, że liryka krajobrazowa zajmuje pokaźne miejsce w każdej poezji europejskiej, w tym też w polskiej i niemieckiej i że istnieje wielewiekowa wspólna tradycja, sięgająca Petrarki i Dantego i ich wzorców antycznych - Teokryta, Wergiliusza, Horacego oraz psalmów i innych tekstów Biblii9.

Wiadomo, że w liryce Miłosza centralne miejsce zajmują krajobrazy Litwy jego dzieciństwa, ale ważne są też inne: polskie, nie wspominając o Francji i Ameryce.

${ }^{5}$ Zob. J.St. Buras, Bibliographie deutscher Literatur in polnischen Übersetzungen. Vom 16. Jahrhundert bis 1994, Wiesbaden 1996.

${ }^{6}$ Przekłady na język polski mieli również liczni inni autorzy Republiki Weimarskiej, w tym Ferdinand Bruckner, Ernst Toller, Erich-Maria Remarque; zob. J. Buras, op. cit.

7 Oskar Miłosz przełożył na francuski słynny Gesang der Geister über den Wassern (Śpiew duchów nad wodami) Goethego (O.V. de L. Miłosz, Chefs-d'oeuvre lyriques du Nord: Angleterre-Allemagne; texte revu, références établies par Jean Bellemin-Noël. Paris 1968, 136-137 (Oeuvres complètes, 10)). Wiersz ten, razem z Hyperions Schicksalslied (Pieśń przeznaczenia Hyperiona) Hölderlina, reprezentuje jakby ton zasadniczy pewnego rodzaju liryki przyrody i krajobrazu, jaką praktykował czasami też Miłosz. (zob. też polski przekład Pieśń duchów nad wodami. Przeł. J. Trzynadlowski, w: J.W. Goethe, Poezje. Red. Z. Żygulski. Zakład im. Ossolińskich, Wrocław 1960, t. II, s. 10. Dusza człowieka / Jest niby woda:/ Spływa z niebiosów,/Wstępuje w niebo/I znowu, znowu/Wraca na ziemię/ Wieczyście zmienna).

8 Wyjątek mógłby jednak stanowić Goethe.

${ }^{9}$ Zob. zbiór Le paysage dans la littérature italienne: de Dante à nos jours. Sous la dir. de Giuseppe Sangirardi. Dijon 2006, oraz monografię K. Stierle, Francesco Petrarca. Ein Intellektueller im Europa des 14. Jahrhunderts. München 2003. 
Z niemieckich poetów stosunkowo najwięcej elementów wspólnych z Miłoszem zawiera na pewno poezja Johannesa Bobrowskiego (1917-1965), który pochodził z Prus Wschodnich i miał polskich, niemieckich i prawdopodobnie również litewskich przodków. Urodził się w Tylży, w centrum tak zwanej ongiś "Małej Litwy“, po matce należał do nadniemieńskiej mniejszości niemiecko-litewskiej (chociaż sam po litewsku nie mówił) i zdawał sobie sprawę z polskich korzeni części swej rodziny ${ }^{10}$. Chętnie zgłębiał staropruskie, bałtyckie tradycje swego regionu, otaczał kultem swego w pewnym sensie rodaka, Chrystiana Donelaitisa, a jako dziecko i uczeń gimnazjalny spędzał wakacje letnie u dziadków w Mociszkach w sąsiednim litewskim Okręgu Kłajpedy (lit. Klaipėdos kraštas) ${ }^{11}$. Prusko-litewski krajobraz nad Szeszupą i Niemnem, którego tam doświadczał, stanie się punktem wyjścia wielkiego projektu pod tytułem Dywan Sarmacki, czyli lirycznego opracowania krajobrazów całej Europy Wschodniej, które poznał jako żołnierz Wehrmachtu (1939-1945) i jako jeniec wojenny nad Donem (do 1949). Do ważnych impulsów dla jego pracy poetyckiej należała świadomość wielowiekowej niemieckiej winy wobec ludów jego regionu (Prusów, Litwinów, Polaków, Żydów) i całej Europy Wschodniej. Projekt nie udał się w zamierzonej objętości, ale ukazały się - w obu częściach Niemiec - trzy znamienite tomy Sarmatische Zeit/Sarmacki czas (1961), Schattenland Ströme/Kraina cieni rzeki (1962) i Wetterzeichen/Znaki pogody (1966).

Bobrowski należy zresztą do licznych niemieckich poetów dwudziestowiecznych, których liryka wiele zawdzięcza Hölderlinowi. Ten młodszy rodak Schillera tworzył szczególnie wartościową lirykę krajobrazową, poświęconą rodzimej Wirtembergii (ale i innym obszarom).

Każdy z trzech poetów nierzadko wiąże temat rodzimych krajobrazów z dalekimi regionami, z krajobrazów tęsknoty rozwija krajobrazy oniryczne i u każdego z nich widać związek między krajobrazem rodzimym, a ideą niebiańskiej ojczyzny człowieka. Łączy ich także wspólne podejście do kwestii prozodii lirycznej. Wszyscy pozostają w konfliktowym stosunku do tradycyjnych systemów wersyfikacyjnych swojej literatury (i epoki). W Niemczech od czasów XVII-wiecznej reformy Martina Opitza dominował system sylabotoniczny - podobnie jak wcześniej w Anglii i w Holandii, a od połowy XVIII wieku także w Rosji. Hölderlin należał do grupy poetów, którzy przeciwstawiali się tej dominacji drogą zapożyczeń z prozodii starogreckiej. Starał się przenieść do poezji niemieckiej sposób wierszowania Pindara, ale też Alkaiosa i Safony. Stąd w końcu rozwinął własny idio-

${ }^{10}$ Zob. jego znaną w Polsce powieść Młyn Lewina; w powieści Litewskie klawikordy daje świadectwo swym litewskim filiacjom.

11 Wiedzę o Bobrowskim czerpię głównie z komentarzy Eberharda Haufego, redaktora edycji wierszy Bobrowskiego (E. Haufe, Erläuterungen der Gedichte und der Gedichte aus dem Nachlass. Stuttgart 1998 (J. Bobrowski, Gesammelte Werke in sechs Bänden; Bd. 5); oraz z obszernego opracowania R. Tgahrt, Johannes Bobrowski oder Landschaft mit Leuten: eine Ausstellung des Deutschen Literaturarchivs im SchillerNationalmuseum Marbach am Neckar. Marbach am Neckar 1993. 
mat bezrymowy, wolnorytmiczny i pełny przerzutni12, który stanie się, już bez odniesień do metrycznych reguł antyku, modelowy dla części niemieckiej poezji XIX wieku (Eduard Mörike, Heinrich Heine w Obrazkach Morza Pótnocnego, Friedrich Nietzsche), a tym bardziej w XX wieku. Rozumie się samo przez się, że działało tu także mnóstwo innych inspiracji, w tym rytm psalmów.

W Polsce sytuacja była bardziej złożona. Co prawda klasycznym systemem wierszowania był sylabizm, podobnie jak w poezji francuskiej i włoskiej, ale od połowy XIX wieku znaczną rolę zaczął obok niego odgrywać także sylabotonizm, którym chętnie posługiwali się jeszcze w XX wieku tak wybitni poeci, jak Julian Tuwim czy Bolesław Leśmian ${ }^{13}$. Własny idiomat rytmiczny rozwija Miłosz wciąż na nowo w ciągłym konflikcie $\mathrm{z}$ oboma systemami, cytując ich fragmenty i łamiąc normy. Czerpie dodatkowe inspiracje z rozmiarów antycznych oraz z rytmu psalmów. Bardzo często obraca się przy tym na pograniczu między prozą a wierszem, jakby wyczerpując wszystkie jego możliwości ${ }^{14}$.

Jeden z najbardziej znanych wierszy krajobrazowych młodszego Miłosza ma tytuł W mojej ojczyźnie.

W mojej ojczyźnie, do której nie wrócę,

Jest takie leśne jezioro ogromne,

Chmury szerokie, rozdarte, cudowne

Pamiętam, kiedy wzrok za siebie rzucę.

I płytkich wód szept $\mathrm{w}$ jakimś mroku ciemnym,

I dno, na którym są trawy cierniste,

Mew czarnych krzyk, zachodów zimnych czerwien,

Cyranek świsty w górze porywiste.

Śpi w niebie moim to jezioro cierni.

Pochylam się i widzę tam na dnie

Blask mego życia. I to, co straszy mnie,

Jest tam, nim śmierć mój kształt na wieki spełni.

Warszawa 1937, (145)

Przestrzeń krajobrazowa pokazana tu jest z perspektywy pamięci, ma jednak charakter mniej oniryczny niż realny. Trzykrotnie zostaje zbudowana na kontraście między "górą" i „dołem": na dole wielkie jezioro, na górze cudowne chmury;

\footnotetext{
12 W. Menninghaus, Hälfte des Lebens: Versuch über Hölderlins Poetik. Frankfurt am Main 2005.

${ }^{13}$ O sylabotonizmie w Polsce zob. M. Dłuska, T. Kuryś, w: Z. Kopczyńska, M. R. Mayerowa (red.), Poetyka. Zarys encyklopedyczny. Dział 3, Wersyfikacja, t. 4, Wrocław 1957.

${ }_{14}$ Obszerniej piszę o tym w artykule Oskar $i$ Czestaw Miłosz - dwaj dysydenci nowoczesności, w: Czestawa Miłosza „strona pótnocna”, op. cit., 297-306.
} 
na dole szept wód i trawy cierniste na dnie, na górze krzyk ptaków i czerwień zimnych zachodów. Wiersz odnosić się może do jeziora Gaładuś na pograniczu polsko-litewskim. Ale obok precyzji topograficznej ważna jest czytelna aluzja zarówno do Świtezi, jak i do Lemanu Mickiewicza oraz funkcjonowanie jeziora, jako obrazu własnej cierpiącej duszy i życia. Ostatnia strofa jednoczy wymiary "góry" $\mathrm{i}$, dołu": „Śpi w niebie moim to jezioro cierni".

Na tle reszty twórczości poety z lat 1930 wiersz ten charakteryzuje się dyskretnym tradycjonalizmem. Przeważa w nim nawiązanie do klasycznego 11-zgłoskowca oraz do struktury rymowej AbbA (z charakterystycznymi odchyleniami od tego modelu). Obok tego słyszy się jednak wyraźne cytaty sylabotoniczne: czterostopowe daktyle pierwszych trzech wersów przechodzą od czwartego wersu w 5-stopowy jamb, który w dalszym ciągu najczęściej odgrywa rolę jakby drugiego głosu - zanim przejawi się w tak wspaniale niuansowanych rytmicznie wersach jambicznych jak „Pochylam się i widzę tam na dnie" i "Jest tam, nim śmierć mój kształt na wieki spełni".

Wierszem krajobrazowym z perspektywy pamięci jest też Die Daubas Bobrowskiego, najbardziej intensywny wyraz tęsknoty poety za krajobrazem dzieciństwa. Litewski toponim daubas (tyle co "wąwóz") oznaczał górzystą i zalesioną strefę na lewym stromym brzegu Niemna niedaleko Ragnety (dziś miasteczko Nieman w obwodzie kaliningradzkim). Krajobraz jest tu zarysowany paroma tylko kreskami: rzeka, brzegi, dźwięczące sitowie, piasek, wieś, i „górą powiał wiatr":

Droben schwang der Wind.

Wir lebten am Fluß in den Hütten.

Dunkelnd die Ufer hinauf, tönte das Schilf.

(I, 69)

Góra powiat wiatr./Mieszkaliśmy nad rzeka w chatach./Rdzawo wspinało się sitowie/ściemniając brzegi.

(Wachowiak, 36)

Wyraźniejszą charakterystykę znajdujemy w strofie

Aber die Gärten, der Schilfstrich

am Strom - jenes Uferland Daubas -

gilbende Scheunen -

und das Gespann, das vom Wald kam -

der Habicht im leeren Blau -

(I, 70)

Lecz owe sady, trzcin pasmo /przy brzegu - kraina nadbrzeżna Daubas - /żótkniejace stodoły - / zaprzeg, wytaniajacy się z lasu - jastrzab w pustym btękicie -

(Wachowiak, 37) 
Inaczej niż w wierszu Miłosza, którego przestrzeń krajobrazowa ze strukturą pionową ("góra" - „dół”) wykazuje pewną stałość, mamy tu do czynienia z wymiarem poziomym. Krajobraz Bobrowskiego "ciągnie się" tudzież zanika dla tych, którzy odchodzą. Przyczynia się do tego czas, który „roniliśmy z dłoni” i który minął. Poza tym istnieje $\mathrm{w}$ wierszu jeszcze inna przestrzeń $\mathrm{i}$ inny czas, które stanowią teraźniejszość podmiotu mówiącego:

noch verfärbts uns die Blicke.

So treten wir unter den Bogen

dieser Jahre. Und zählen

unsre Freuden der Erde zu. -

$(\mathrm{I}, 70)$

jeszcze zabarwi nam spojrzenia./Tak wstęujemy pod sklepienie/owych lat. I

przypisujemy/nasze radości ziemi.-

(Wachowiak, 37)

W związku z tym liryczny opis utraconego krajobrazu dzieciństwa przekształca się $\mathrm{W}$ refleksję nad czasem - a czas przejawia się w postaci pór roku („mrozy i deszcze, gromy i chmury"; "owoce”; "zimy”), ale też jako czas utracony i ipso factu czas utraty:

wie die Zeit,

die wir nahmen

und gaben sie aus den Händen,

rot von Früchten

$(\mathrm{I}, 69)$

jak ów czas,/który braliśmy /oddając go z rąk,/czerwony[ch] od owoców

(Wachowiak, 36)

Das ist vergangen.

Wir ließen die Dörfer dem Sande.

Kaum wie ein Flößerruf

zogen wir fort.

Folgend der Bitternis, legen

wir Holz zu den Feuern der Fremde

(I, 69)

To przeminęło./Wsie zostawiliśmy piachom./Prawie jak okrzyk flisaka/oddaliliśmy się. //Oddani goryczy, doktadaliśy /drewno do ognisk obcości [...]

(Wachowiak, 36)

Rytmy tego wiersza na pierwszy rzut oka są dalekie od tekstu Miłosza. Wersy są krótsze, pełne przerzutni, stanowią echo wolnorytmicznego idiomatu Hölderlina. Ale odnajdziemy tu też cytaty z innej prozodii, głównie daktylicznej, a jednak 
z taktem na cztery czwarte niemieckiej pieśni popularnej - zob. „Wir lebten am Fluß in den Hütten” (v-vv-vv-v); „Dunkelnd die Ufer hinauf” (-vv-vv-); „kamen Fröste und Regen” (-v-vv-v); „Blitz und Gewölk, wie die Zeit” (-vv-vv-); „Wir ließen die Dörfer dem Sande” (v-vv-vv-v); „Kaum wie ein Flößerruf" (-vv-v-).

Między Die Daubas i $W$ mojej ojczyznie istnieje pewne podobieństwo, które bynajmniej nie oznacza identyczności. Utrata krajobrazu dzieciństwa u Miłosza i u Bobrowskiego nastąpiła wszak z innych powodów.

Dodajmy jeszcze przykład z Hölderlina. On także nierzadko opisuje rodzimy krajobraz niczym tęskniący emigrant, a ponadto i u niego krajobraz ten ma akcent metafizyczny. Oto kilka fragmentów z wiersza Mein Eigentum (strofa alcejska):

\section{Mein Eigentum}

In seiner Fülle ruhet der Herbsttag nun,

Geläutert ist die Traub und der Hain ist rot

Vom Obst, wenn schon der holden Blüten

Manche der Erde zum Danke fielen.

$[\ldots]$

Zu mächtig, ach! ihr himmlischen Höhen, zieht

Ihr mich empor, bei Stürmen, am heitern Tag

Fühl ich verzehrend euch im Busen

Wechseln, ihr wandelnden Götterkräfte.

Doch heute laß mich stille den trauten Pfad

Zum Haine gehn, dem golden die Wipfel schmückt

Sein sterbend Laub, und kränzt auch mir die

Stirne, ihr holden Erinnerungen!

Und daß mir auch, zu retten mein sterblich Herz,

Wie andern eine bleibende Stätte sei,

Und heimatlos die Seele mir nicht

Über das Leben hinweg sich sehne,

Sei du, Gesang, mein freundlich Asyl! sei du,

Beglückender! mit sorgender Liebe mir

Gepflegt, der Garten, [...].

(Parafraza15: Moja własność. Wspaniaty jesienny dzień, winogrona i owoce dojrzaty ku radości ludzi. Moce boskie, zbyt gwattownie porywacie mnie w góre jak burze w pogodny dzień. Pozwólcie dziś mi korzystać w ciszy z pięknej jesieni, „ażeby i dla mnie, uratować moje śmiertelne serce, by istniato jak dla innych state miejsce, / I żeby moja pozbawiona ojczyzny dusza nie tęsknita poza granice życia, / Bądź ty, pieśni, mi przyjaznym azylem", bądź moim ogrodem, który będę uprawiał z mitościa)

${ }^{15}$ Nie mając do dyspozycji polskiego przekładu Hölderlina, podaję tu i w innych miejscach moją parafrazę. 
Przejdźmy do dwóch wierszy Miłosza na temat równin centralnej Polski, Równina i Ranek (z tomu Ocalenie 1945 r.), i porównajmy je z Równina sarmacką Bobrowskiego.

Liryczny opis krajobrazu mazowieckiego w Równinie (169) jest znacznie bardziej szczegółowy niż w W mojej ojczyźnie lub w Daubas, przy czym poeta podkreśla jego długoletnią nieodmienność, prawie że ponadczasowość: „Od lat, od lat, ta sama, niepojęta". Jego rozległość, mieniąca się koniczyna, kartofliska, smugi pyłów, roje komarów, niskie chmury nad wszystkim - to już tyle samo detali, ile w poprzednich wierszach obu poetów. Dochodzą do tego różne pory roku: „Biel zim, kos błyski, pożary i dymy,/ Zwalone skrzydła na przemian się wloką". Nie brak tu też ludzi, w odróżnieniu od poprzednich wierszy: „Z gromadami kobiet na kartofliskach./ Z pólkiem, gdzie koniczyna mieni się nie zżęta,/ Z komarów długą skrą przy końskich pyskach." (ibidem)

Niepojętej nieodmienności tej równiny tylko na moment przeciwstawia się rzeczywistość wojenną i okupacyjną - w tonacji prowokacyjnie spokojnej. Raz pojawia się grupa pielgrzymów lub niemieckich wozów wojennych (z krzyżami Wehrmachtu) obwieszonych jesiennymi liśćmi: „Łaskę witamy, czy w ziemię schodzimy -/ Ona szeroko.// Ni słup objawień, ani krzak Mojżesza/Na widnokręgu krańcach nie wystrzeli./ Ci, których krzyże wiatr liśćmi obwiesza,/ Też nie wiedzieli."

Innym razem pojawiają się „Twierdze czerwone, rozchwiane stolice,/ Skrzydeł na niebie i drutów potoki”, ale "Na chwilę są i sypią się w pył. / Gdzież łuski murów, łun ruchome bicze, / Gdzie rdzawe baszty? Ja widzę obłoki / I dzień, jak wtedy, przed czasami, był" (170). Jednym słowem, niepojęta równina nie ulegnie żadnym katastrofom.

Wierszowanie tego utworu jest jeszcze bliższe tradycji niż przytoczone powyżej teksty Miłosza. Ma przejrzysty schemat rymowy (ABAB), czasami z rymami na przemian męskimi i żeńskimi, ma też wyraźne nastawienie na 11-zgłoskowiec, przy czym pojawia się kilkakrotnie - nie wiadomo czy jako urywek jakiejś znanej melodii, czy jako rytmiczny motyw przewodni - wers o czytelnym profilu 5-stopowego jambu: „Od lat, od lat, ta sama, niepojęta” (dwa razy), „Ni słup objawień, ani krzak Mojżesza”, "Od niej, od słońca oczy ręką skrywać”, „I dzien, jak wtedy, przed czasami, był”, „Na twardej ścieżce przewrócony pług”. Czy motyw ten - dziwnie spokrewniony z śpiewnym motywem w Daubas Bobrowskiego - ma wskazywać na pierwiastek nadziei, który zawarty jest w niewzruszoności równiny?

Podobny obraz polskiego pejzażu przedstawia wiersz pt. Ranek:

Pod równy deszczu szum, w poranek mglisty, W pianiu kogutów, w gęsi długim krzyku 
Budzi się senna wieś i kraj ojczysty

Dymami ścieli się w dolinach świtu.

$(186)^{16}$

Horror okupacyjny przywołuje się dopiero w drugiej zwrotce - w postaci złego snu.

W tej sytuacji pomaga nie pamięć o „italskich winnicach, zieleni Anglii”, nic nie daje tu też liryka skargi i lamentu Syrokomli i Niekrasowów ${ }^{17}$ - lecz rekurs do poetyki nadziei, a nawet utopii: „Jak złota kula wiersz niech się otworzy / I wyjdzie stamtąd w blasku ziemia inna" (186-187).

Nadzieję uzmysławiają „słoneczne pałace przyszłości”, które w wymarzonej przyszłości będą zastępowały obecne piaski, burzany, karłowate sosny i „zaśnieżoną strzechę":

$\mathrm{Tu}$, na tych polach, gdzie burzany rosną,

Staną słoneczne przyszłości pałace

I nad piaskami, karłowatą sosną

Dźwięk ciemny skrzypiec zapłacze.

$[\ldots]$

A kiedy szminkę obmyją aktorzy

I ciemność błyśnie na umilkłym basie,

Jeszcze tym echem piękność się pomnoży

I z każdej rzeczy promieniować zda się.

Zarysowana $\mathrm{w}$ tych ustępach wizja przyszłości nie jest zupełnie obca socrealizmowi, chociaż podana trochę w tonie bajki („złota kula") i - zamiast monumentalnych zakładów przemysłowych - pojawiają się w niej pałace nowego piękna, które będzie „promieniować z każdej rzeczy”. Obok wzmianek o Syrokomli i Niekrasowie wiersz zawiera aluzje do Norwida (rym ,jeszcze - deszczem"), Słowackiego („I znów nie czas, nie czas żałować róż...”) i Żeromskiego (słoneczne pałace i „smętek nad Wisłą").

Bobrowski $\mathrm{w}$ swych licznych wierszach krajobrazowych $\mathrm{z}$ reguły rzadziej mówi wprost o kwestiach społecznych, etnicznych i rzeczywistości wojennej. Natomiast dobitnym przykładem charakterystycznego poetyckiego ujęcia tej ostatniej jest jego znany wiersz Die Sarmatische Ebene/Sarmacka równina, który pod kilkoma

${ }^{16}$ Szlembark, podana pod tekstem wiersza miejscowość powstania (?) wiersza, co prawda położona jest już w górzystym regionie podhalańskim, ale nastrój i charakter opisanego krajobrazu jest tu taki sam, co w Równinie: „kraj ojczysty / Dymami ścieli się w dolinach świtu”.

17 [...] Wy, coście nie umieli od skarg się wyzwolić,/Ty, Syrokomla jakiś czy Niekrasow.// Jakże rozumiem was! Jak pieśń się łamie,/ Gdy na niej ciąży rozpacz ludzi ciemnych!/[...]// Ale cóż warta piękność, co się trwoży,/ I w trudnych latach miary nie utrzyma. 
względami nadaje się do porównania z wierszami Miłosza o polskich równinach. Przynosi on jakby poetycką i mityczną syntezę krajobrazów nad Wisłą i Wołgą:

Ebene,

riesiger Schlaf,

riesig von Träumen, dein Himmel

weit, ein Glockentor,

in der Wölbung die Lerchen,

hoch -

$(\mathrm{I}, 31)$

Równino, / Ogromny śnie,/Ogromny marzeniami, twe niebo/Szerokie, brama dzwonu,/ w sklepieniu skowronki, / wysoko -

(Wachowiak, 55)

Ślady wojny są $\mathrm{w}$ tym wierszu aluzyjne i na pierwszy rzut oka toną w hymnicznym tonie całości. Ale już pierwsza zwrotka przynosi wątek „dnia z odkrytymi żyłami":

Seele,

voll Dunkel, spät -

der Tag mit geöffneten

Pulsen, Bläue -

die Ebene singt.

$(\mathrm{I}, 30)$

Dusza, / petna zmroku, późno - / dzień z otwartymi / Żyłami, błękit -, / równina śpiewa (Wachowiak, 54)

A „roztłuczone szkło łez”, ,zgliszcza” i „ popiołu ślad” na drogach „twoich wiosek" są u Bobrowskiego wymownymi sygnałami nieszczęść, które dotknęły wszystkie ludy tej części Europy:

Und

die Dörfer sind dein.

Dir am Grunde grünend,

mit Wegen,

schmal, zerstoßenes Glas

aus Tränen, an die Brandstatt

gelegt deiner Sommer:

die Aschenspur,

$(\mathrm{I}, 30)$

I / wioski sa twoje. / Tobie zieleniejącej na dnie,/ z waskimi, /drogami rozttuczone szkło/ łez, przy zgliszczach/złożony twoich okresów lata:/ popiołu ślad

(Wachowiak, 55) 
Bobrowski przypomina $\mathrm{w}$ tym wierszu także długą, mityczną historię „równiny sarmackiej”. Historię tę śpiewa „falująca pieśn”" równiny, którą słyszą „miasta starego dźwięku":

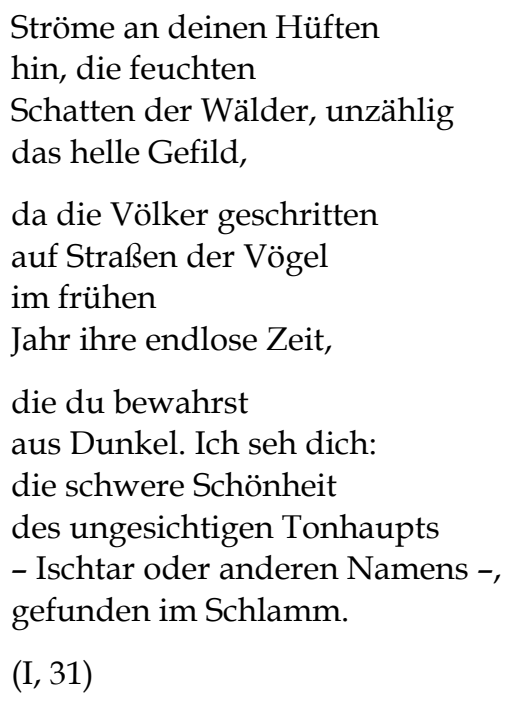

Strumienia na twoich biodrach/tam, wilgotne/cienie lasów, niezliczony/jasny łan, //bo ludy weszly/na ptaków szlaki/wiosna/ ich nieskończony czas,/który zachowujesz/z mroku,/ Widze ciebie:/ciężk urodel glinianej głowy bez twarzy/- imieniem Isztar/albo cię zwa inaczej /odnalezionej w mule.

(Wachowiak, 55-56)

"Ich czas nieskończony//który zachowujesz/ z mroku” tworzy w wierszu Bobrowskiego kontrast $\mathrm{z}$ czasem wojny i zniszczenia, połyka go w mitycznym mroku. Natomiast w wierszach Miłosza bezbrzeżny czas nędzy osiąga szczyt w okresie katastrofy okupacji niemieckiej, a zawiera nadzieję na lepszą przyszłość.

Jako pierwszy wiersz przekraczający sarmackie strony omówimy słynny tekst Miłosza pt. Ziemia. Jest to niepokojący wyraz nieufności człowieka, który przeżył wojnę, nawet wobec piękna przyrody i krajobrazu „słodkiej ojczyzny” Europy:

\section{Ziemia}

Słodka moja europejska ojczyzno,

Motyl siadając na twoich kwiatach plami skrzydła krwią,

Krew się zbiera w paszczy tulipanów.

Gwiazdą mieni się na dnie powojów

I spłukuje ziarna twego zboża. 
Twoi ludzie grzeją sine ręce

Przy woskowej gromnicy pierwiosnka

I na polach słyszą jak zawodzi

Wicher w lufach ustawionej broni.

Ziemią jesteś, gdzie nie wstyd jest cierpieć,

Bo usłużą szklanką gorzkich płynów

W której na dnie jest trucizna wieków.

W twój rozdarty wieczór mokrych liści,

Nad wodami w których dotąd płynie

Rdza zapadłej zbroi centurionów,

U podnóża potrzaskanych wieżyc,

W cieniu przęseł jak cień akweduktów,

Pod spokojnym baldachimem skrzydeł sowy,

Mak czerwony, ścięty szronem łez.

Washington DC, 1949

Wiersz swobodnie gra z formatem 10-zgłoskowca bezrymowego oraz z reminiscencją znanego krótkiego hymnu Ignacego Krasickiego [Święta mitości kochanej ojczyzny]. Jest to gorzki komentarz do moralnej sytuacji Europy powojennej. Przedstawiony pejzaż kontynentu ma charakter hybrydyczny. Pierwsze zwrotki a także ostatni wers - wymieniają szczegóły, które występują w całej Europie: motyl, kwiaty, tulipany, powoje, pierwiosnek, a na samym końcu czerwony mak; „rozdarty wieczór mokrych liści” też jest wszędzie spotykany, ale u Miłosza wskazuje raczej na strony sarmackie; zaś ostatnie strofy przywołują tereny dawnego imperium rzymskiego: centuriony, akwedukty. Moralne obwinianie Europy przenosi się jednak aż na jej przyrodę.

W 1951 lub 1952 Bobrowski napisał Europejską odę (podobno nie przełożoną na polski), w strofach zbliżonych do safickich, gdzie mowa jest o „bezmiarze winy” kontynentu. Oto początek:

Europäische Ode

Deine Kathedralen umraucht Verwesung.

Noch ist an den Türen die Blutschrift deiner

Zwingherrn nicht verblaßt. Und der Bosheit Siegel

prägt deine Stirn noch.

$[\ldots]$

(1951-52; II, 192-193)

Krajobraz Europy jest tu charakteryzowany słowem-kluczem „katedry”, na bramach których jeszcze widnieje "krwawe pismo” uzurpatorów. Na pierwszy 
rzut oka mogłoby się wydawać, że poeta ma na myśli raczej katolicką i protestancką Europę, ale znając jego podziw dla Rosji, należy tu uwzględnić również wspaniałe sobory prawosławne ${ }^{18}$. Kogo dokładnie miał na myśli, mówiąc w odzie o wyzwolicielach Europy, jako o „barbarzyńcach o obcych twarzach, i innych, których się [Europa] wyrzekła"? Na pewno ludy Związku Radzieckiego i Polaków, a chyba też Amerykanów oraz Żydów. Tych parę ostrożnych refleksji niech nam wystarczy dla sformułowania następującej uwagi: jeżeli w ustach Miłosza nie budzi zastrzeżeń obciążenie winą całej Europy, podobne posunięcie u poety niemieckiego, byłego żołnierza Wehrmachtu, jest na pewno rzeczą bardziej wątpliwą, nawet jeżeli tę strofę uznamy za tragiczny zwrot do samego siebie „Kann dies gelten...": „Czy to może się liczyć, że często wzdrygałeś się/w nocy albo też w dzień na sekundy?/Chętnie za takie odczucie drobne, przelotne/ Mordercy siebie uniewinniają" "Kann dies gelten, daß es dich oft geschaudert / nachts und auch am Tag für Sekunden manchmal? / Gern für solch ein flücht'ges Gefühlchen sprechen / Mörder sich schuldlos«" (II, 193) ${ }^{19}$.

Gorzki europejski wiersz Miłosza jest $\mathrm{w}$ pewnym sensie spokrewniony $\mathrm{z}$ jego wcześniejszą (z 1947 r.) reakcją liryczną na piękno amerykańskiego krajobrazu. Mowa o liryku Na śpiew ptaka nad brzegami Potomaku. Omawiamy go jako pierwszy przykład połączenia opisu krajobrazu północnoamerykańskiego i sarmackiego. Na uwagę zasługuje regularny (z niewieloma wyjątkami) jedenastozgłoskowiec, bez rymów:
Na śpiew ptaka nad brzegami Potomaku
Kiedy zakwita magnoliowe drzewo
I park zielonym zmąca się obłokiem,
Słyszę twój śpiew nad brzegiem Potomaku
W uśpione płatkiem wiśniowym wieczory.
$[\ldots]$

\section{(I, 151-152)}

Punktem wyjścia jest przejmujące piękno amerykańskiej przyrody: drzewa magnoliowe, drzewa wiśniowe, które w zielonym parku przy rzece Potomak (najprawdopodobniej West Potomac Park) "usypiają wieczory” swymi płatkami, i śpiew ptaka. Poeta miesza to wrażenie ze wspomnieniami polsko-litewskimi. Przemieszanie to odbywa się $\mathrm{w}$ trybie zaprzeczonego wspomnienia, które przywołuje znany $\mathrm{z}$ folkloru słowiańskiego i bałtyckiego proceder porównania zaprzeczonego ${ }^{20}$ : „Mnie to niemiłe. Po cóż mi wspominać / Żółte od liści młodziutkich

${ }^{18}$ Zob. też jego wiersz Kathedrale 1941 (I, 130) o soborze nowogrodzkim i jego zniszczeniu.

${ }_{19}$ Przekład mój - RF.

${ }^{20} \mathrm{O}$ XIX-wiecznym odkryciu i późniejszym badaniu tego procederu zob. F. J. Oinas, KarelianFinnish Negative Analogy: A Construction of Slavic Origin. „The Slavic and East European Journal”, Winter 1976, nr 4, vol. 20, 379-386 (za tę informację dziękuję J. Herlthowi). 
Ponary /[...]Po cóż mi znowu [...]". Rozumie się, że ten proceder wzmacnia element wspomnienia, z przejmującym akcentem ironii - bo „żółte od liści młodziutkich Ponary" były w latach 1941-1944 miejscem systematycznych niemieckich masakr. Imię Zygmunta Augusta wskazuje zarówno na wileńską szkołę poety, jak i na polsko-litewskiego króla i wielkiego księcia z XVI wieku; zabawy dworzan króla Władysława (zapewne IV) mieszają się z życiem towarzyskim filomatów Mickiewicza oraz młodego Miłosza i jego kolegów, tworząc jakby jedność wspomnieniową. Wiersz kończy się paradoksalnym zwrotem do ptaka, którego śpiew wywołał te wspomnienia: „Śpiewaj! Na perłę popielatych wód/Syp rosę pieśni z brzegów Potomaku”. „Perła popielatych wód” jest zapewne aluzją do szczególnego koloru rzek sarmackich, ale prawdopodobnie również do popiołów zmarłych, które ze sobą przenoszą.

Przykładem poetyckiego krajobrazu panoramicznego jest słynny wiersz Przed krajobrazem. Na wstępie przedstawiony zostaje północnoamerykański pejzaż rzeczny oraz górski, który stanowi wododział, tzn. punkt, w którym wody Atabaski zaczynają podążać aż w trzech różnych kierunkach: w stronę Pacyfiku, Atlantyku oraz daleko na północ, do Oceanu Arktycznego. Z dużą dozą prawdopodobieństwa chodzi o Snow Dome, szczyt w kanadyjskich Górach Skalistych. Spływająca z gór na północ rzeka Atabaska wyzwala u Litwina wspomnienia:

Tylko jedna stężona rzeka struży się prosto na północ,

Gdzie przezroczysta szarość w złotawej górskiej bramie,

Szarość ogromnej ciszy, blade jeziora,

I bagienna jedlina jeszcze tysiąc mil

Aż do granicy, pustki polarnej.

$[\ldots]$

Wspomnienia uruchamiają mityczne wyobrażenie o jedności własnego ciała z ziemią:

W moich snach ziemia była jednością mojego ciała,

Tutaj nad Athabasca i wszędzie gdzie żyłem, wędrowny

(Ibidem)

- a wyobrażenie to przechodzi $\mathrm{w}$ mityczne wyolbrzymienie osoby poety - tzn. pomnożenie jego siły i znaczenia - na drodze kosmiczno-geologicznej transformacji. Całość przypomina mityczne wyobrażenia o powstaniu ludzkości w wyniku monumentalnych walk tytanów i smoków:

Opierałem rękę o spiętrzenie gór.

Delty kroiły mnie w upale smoczych pobojowisk.

I czekałem, nie mając w języku wyrazów, 
Żeby nazwać to wszystko co moje i ziemi,

Aż duch jakiś, z wulkanicznych mutacji poczęty,

Krzyknie i odczaruje nasze prawdziwe imię.

(ibidem)

W tym miejscu warto przypomnieć ogromne geograficzne obszary niektórych wierszy Hölderlina, w tym jego hymn poświęcony Dunajowi, Der Ister. Utwór ten zaczyna się od ewokacji skomplikowanego wododziału między Dunajem a Renem, a w dalszym toku rozszerza ją na Grecję i Indus:

Wir singen aber vom Indus her /Fernangekommen und /Vom Alpheus

(...) Myśmy znad Indu,/Alfejosa,/Z daleka niesiem nasza pieśń./ (... $)^{21}$

Odsyłając do trochę obszerniejszej interpretacji tego wiersza22 zaledwie dotykamy tu jego wymowy symbolicznej: Rzeka występuje jako „znak nieba w suchym"23, aluzyjnie też jako obraz duszy ludzkiej, a w ukryciu jako mitologiczny autoportret poety, który kojarzy siebie z gigantem Istrem, czyli Dunajem, jednym $\mathrm{z}$ „dzieci nieba”. Wiersz Miłosza Przed krajobrazem co prawda rezygnuje z greckich aluzji mitologicznych, ale także w nim dochodzi do kosmicznego utożsamienia poety z monumentalnym krajobrazem.

Inny tekst Hölderlina, Der Wanderer/Wędrowiec, interesuje nas jako wiersz krajobrazowy o całym wręcz świecie, który trochę przypomina gatunek „pejzażu światowego" występującego u malarzy: Jana Breughla i Joachima Patinira ${ }^{24}$. Utwór mówi o "afrykańskich suchych/równinach”, o bezdrzewnych górach w gorącej strefie klimatycznej (w kontraście z rodzimym europejskim - wirtemberskim - krajobrazem gór z lasami i gajami, strumykami i źródłami) oraz o oderwanym od ludzkiego życia lodowatym biegunie północnym. Obie te strefy odbierają poecie czas. Starzejąc się, wraca do stron ojczystych, wykonując jakby ostatni krok przed wejściem do ojczyzny wiecznej, gdyż umarł on dla bliskich - a oni dla niego (275-276).

${ }^{21} \mathrm{~F}$. Hölderlin, Ister (Der Ister), w: idem, Co sie ostaje, ustanawiaja poeci. 100 najstynniejszych wierszy w przekładzie Antoniego Libery, Gdańsk 2009, wydanie drugie rozszerzone, s. 162-164 (Dziękuję Pani Mirosławie Zielińskiej).

${ }^{22}$ Rzeka i rzeki, op. cit.

23 „Umsonst nicht gehen / Im Trocknen die Ströme”.

${ }^{24}$ Za tę wskazówkę dziękuję Hildzie Fieguth. Zob. opracowania D. Zinke, Patinirs „Weltlandschaft": Studien und Materialien zur Landschaftsmalerei im 16. Jahrhundert, Frankfurt a.M. 1977, M. Paulussen, J. Brueghel d.Ae. Weltlandschaft und enzyklopädisches Stilleben, Aachen: Diss. RheinischWestfälische Technische Hochschule 1997 oraz katalog Die Entdeckung der Landschaft: Meisterwerke der niederländischen Kunst des 16. \& 17. Jahrhunderts: Staatsgalerie Stuttgart, 15. Oktober 2005 - 5. Februar 2006. Red. E. Wiemann; J. Gaschke, M. Stocker, Köln 2005. 
Bobrowski z pewnością znał utwór pt. Der Wanderer Hölderlina i można przypuszczać, że to na niego zareagował krótkim wierszym, który nosi ten sam tytuł. Krajobraz pierwszej zwrotki obejmuje całość równiny sarmackiej, co nie wyklucza osobnej aluzji do krainy położonej nad Niemnem:

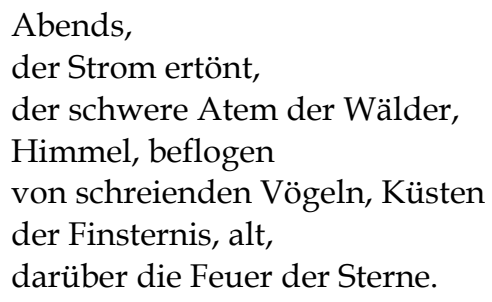

Abends, der Strom ertönt, der schwere Atem der Wälder, Himmel, beflogen von schreienden Vögeln, Küsten der Finsternis, alt, darüber die Feuer der Sterne.

Wieczorem,/rozbrzmiewa rzeka,/ciężki oddech borów,/niebo, latają na nim/rozkrzyczane ptaki, wybrzeża/ciemności, dawne/nad nimi ognie gziazd

(Wachowiak, 102)

Zamiast poszerzenia perspektywy geograficznej, jak u Miłosza i Hölderlina, znajdujemy tu wzmianki o licznych bramach egzystencjalnych czy metafizycznych. Każda z tych bram jest otwarta i zaprasza do krajobrazu wiecznego, który jest zawsze ten sam:

Menschlich hab ich gelebt, zu zählen vergessen die Tore, die offenen. An die verschloßnen hab ich gepocht.

Jedes Tor ist offen.

Der Rufer steht mit gebreiteten

Armen. So tritt an den Tisch.

Rede: Die Wälder tönen, den eratmenden Strom durchfliegen die Fische, der Himmel zittert von Feuern.

Po ludzku żyłem, / liczyć zapomniatem bram/otwartych. Stukatem / do zamkniętych. // Każda brama otwarta. / Wotający stoi z rozprostartymi/ramionami. Tak przystap do stotu. / Mów: Bory szumia, / oddychaja rzeka / przylatuja ryby, niebo /drży ogniem.

(Wachowiak, 102)

W metafizycznych aluzjach tego rodzaju możemy dostrzec wspólne miejsca Miłosza, Bobrowskiego i Hölderlina.

Na zakończenie omówimy pokrótce Miasto bez imienia (1969), odmianę Miłoszowskiej liryki krajobrazowej, która pod niejednym względem odpowiada dąże- 
niu poety do „formy bardziej pojemnej”. Dążenie to przejawia się w swobodnym traktowaniu wersów, ale też w zestawieniu heterogenicznych tekstów. Są to liryki o nierównej "gęstości", notatki prozą, cytaty ze starszych druków, a całość przypomina trochę kartotekę, trochę antologię, trochę wolną kompozycję cykliczną, a trochę szkice do większego poematu. Zbiór ten zawiera między innymi najważniejszy komentarz liryczny poety na temat Ameryki. Zaczyna się od wiersza Rok, który przypomina pamiętny rok 1965 w Berkeley (początek światowej rewolty młodzieży studenckiej). W jego długich wersach poeta ewokuje nie tylko ekstatyczną, młodzieżową muzykę rock and rolla, ale również kalifornijski krajobraz:

Był to wysoki rok, lisowatego koloru, jak przecięty pień redwoodu albo na pagórkach liście winogradu w listopadzie

Po tym wierszu-wprowadzeniu następuje seria dwunastu numerowanych liryków nierównej długości pod tytułem Miasto bez imienia. Pierwszy przynosi uobecnienie Wilna w postaci syntezy z różnych okresów historycznych (Wielka Armia Napoleona 1812, Kongres Wiedeński 1815, międzywojnie - ale też aluzja do niemieckich masowych egzekucji w Ponarach 1941-1944).

Wspomnijmy w tym miejscu pokrótce o wierszu Bobrowskiego Die alte Heerstraße / Stary wojenny szlak:

Seitab ist gezogen

auf der verfallenen Straße

der Korse, ein südlicher Kaiser,

winzig vor Zorn, in der Krähen

Spur auf dem Schnee, -

eingeholt von heiligen

Flüchen abends. Die hungernden

Wölfe schleiften Nächte

aus Moordunst ihm nach

(I, 16-17)

Na stronie szedt / zniszczona szosa / Korsykanin, poludniowy cesarz, / drobny z gniewu, wron / śladami na śniegu, - / dosięgany świętymi / przekleństwami wieczorem. Głodujące / Wilki wlokty za nim / noce z wyziewu trzęsawisk ${ }^{25}$

Wzmianka o Korsykaninie wskazuje zapewne na ucieczkę Cesarza Francuzów po klęsce rosyjskiej, ale w poetyce Bobrowskiego wątek ten zawiera także aluzję do przerażających czasów II wojny światowej ${ }^{26}$.

25 Przekład mój - RF.

${ }^{26} \mathrm{~W}$ tym wierszu pojawia się także motyw Eurydyki i Orfeusza, którym autor przekształca tęsknotę za stronami nadniemieńskimi w uniwersalny motyw daremnej tęsknoty poety. 
Wróćmy jednak do pierwszego, „wileńskiego" liryku Miłosza w zbiorze Miasto bez imienia. W trzeciej strofie niespodziewanie występuje tam amerykański wtręt wspomnienie o amerykańskiej teraźniejszości i o amerykańskim krajobrazie:

Tej wiosny na pustyni, za masztem obozowiska, a cicho było aż po litą skałę gór żółtych i czerwonych, usłyszałem w szarym krzaku brzęczenie dzikich pszczół,

Brzęczenie dzikich pszczół w szarym krzaku to wątek o znacznym ciężarze znaczeniowym, gdyż wskazuje on na nadejście inspiracji poetyckiej (pszczoły jako antyczne symbole poetów), jeśli nie na dźwięk głosu Boga.

W liryku 2. forma staje się bardziej pojemna; mowa jest o Dolinie Śmierci, którą nie każdy czytelnik zidentyfikuje z kalifornijską Death Valley:

2.

W Dolinie Śmierci myślałem o sposobach upinania włosów.

O ręce która przesuwa reflektory na studenckim balu w mieście skąd żaden głos już nie dosięga.

Minerały na sąd nie trąbiły.

Osypywało się z szelestem ziarnko lawy.

W Dolinie Śmierci błyszczy sól na dnie suchego jeziora.

Broń się, broń się, mówi tykot krwi.

Z litej skały nadaremnej żadna mądrość.

W Dolinie Śmierci na niebie ni orła ani jastrzębia.

Wróżby cyganki zostały spełnione.

W zaułku pod arkadami czytałem wtedy poemat

o kimś kto mieszkał tuż obok, pod tytułem „Godzina myśli“.

Dlatego patrzyłem w lusterko, tam jeden na trzysta mil

szedł człowiek: Indianin prowadzący rower pod górę.

(554-555)

W tych wersach dochodzi do systematycznego przenikania reminiscencji litewskich i wileńskich oraz amerykańskiej Death Valley. Krajobraz amerykański jest tu prawie zupełnie kamienny, nagi i pozbawiony roślin. Tę przestrzeń śmierci ożywiają wątki wileńskie, wspomnienia bardzo prywatne, ale też literackie, w tym implicytnie do Mickiewicza27, a eksplicytnie do Słowackiego, autora Godziny myśli.

W 8. i 9. liryku serii jałowa przyroda amerykańska doznaje swoistej apoteozy. „Świętowanie Niekonsystencji” przywołuje atrybuty Doliny Śmierci, bo jest „palą-

27 „W mieście skąd żaden głos już nie dosięga” (554) zawiera aluzję do początkowego utworu Sonetów krymskich A. Mickiewicza. 
ce ostre cierpkie słone”, chociaż może się odbywać wszędzie, „w zatoce, na płaskowyżu, w suchym arroyo" (557-558) - czyli w rozmaitych wcieleniach krajobrazu amerykańskiego. Wysokiemu i jasnemu światłu Kalifornii przeciwstawia poeta niskie światło stron rodzimych:

9.

Uniwersalne światło a ciągle się zmienia.

Bo kocham także światło, może tylko światło.

Jednak co za jasne i za wysokie to nie dla mnie.

Więc kiedy różowieją obłoki myślę o świetle niskim,

jak w krajach brzozy i sosny obleczonej chrupkim porostem,

późną jesienią, pod szronem, kiedy ostatnie rydze

dogniwają w borkach i psy gonią za echem,

a kawki krążą nad wieżą bazyliańskiego kościoła.

Przeciwstawienia te naturalnie świadczą o tęsknocie poety za stronami rodzimymi. Dopuszczają jednak też myśl o niespodziewanej atrybucji pewnego metafizycznego sensu właśnie nagiej przyrodzie amerykańskiej. Wysokie i jasne światło Ameryki może oznaczać wysoką i jasną metafizykę, przed którą poeta woli uciec do niskiego światła ,jak w krajach brzozy i sosny obleczonej chrupkim porostem”. Możliwe też, że „miasto bez imienia” nie musi wiązać się z ideą Miasta Niebiańskiego i że Wieczność symbolizuje właśnie to, co wiecznie obce, ostre i dalekie od życia.

Dziwną paralelę z taką - możliwą - interpretacją znajdujemy w przytoczonym tu już wierszu Hölderlina Der Wanderer:

Einsam stand ich und sah in die afrikanischen dürren/Ebnen hinaus; vom Olymp regnete Feuer herab, / Reißendes! milder kaum, wie damals, da das Gebirg hier/Spaltend mit Strahlen der Gott Höhen und Tiefen gebaut./Aber auf denen springt kein frischaufgrünender Wald nicht/In die tönende Luft üppig und herrlich empor./[...]/Um der Haine Gesang, ach! um die Gärten des Vaters/Bat ich vom wandernden Vogel der Heimat gemahnt./ Aber du sprachst zu mir: Auch hier sind Götter und walten,/Groß ist ihr Maß, doch es mißt gern mit der Spanne der Mensch.

(Parafraza: Samotnie patrzyłem na afrykańskie suche równiny pod deszczem ognia olimpijskiego; daremna była moja modlitwa o zielone lasy, gaje lub ogrody ojczyzny. Odpowiedź brzmiała "Także tu sa bogowie i rzadza, / Wielka jest ich miara, lecz chętnie przykłada człowiek miare piędzi")

Paralela między afrykańską pustynią Hölderlina a kalifornijską Death Valley Miłosza może nie być jednoznaczna - niewykluczone, że oba wiersze mają ten sam antyczny wzorzec: Panegyricus Messallae nieznanego nam autora z Corpus Tibulla- 
num (III, 7= IV,1). Ta krótka epopeja panegiryczna $\mathrm{w}$ heksametrach opisuje wędrówkę bohatera przez dalekie od życia strefy świata oraz jego trudny powrót do słodkiej ojczyzny ${ }^{28}$.

Przyznam, iż rozważania porównawcze o wierszach, które z całą pewnością nie pozostają ze sobą $\mathrm{w}$ relacji świadomie podjętego dialogu, wymagają szczególnego uzasadnienia. Cechy wspólne oraz kontrasty, które wskazaliśmy, ujawniają europejską wspólnotę, której czasem nie doceniamy w naszej codziennej pracy literaturoznawczej, a która istnieje nawet między poetami, w pewnym sensie stojącymi tyłem do siebie. Wspólna tradycja antyczna, tudzież wielowiekowa poantyczna, chrześcijańska europejska tradycja poezji opiewającej naturę i krajobrazy, wywodzona również z antyku i z Biblii, stanowi najogólniejszy fundament tej wspólnoty. W tym miejscu warto zasygnalizować, że ezoteryczna kraina Lauda Miłosza i wiersz o tym samym tytule ${ }^{29}$ dałyby się porównać z poetyckimi szkicami Hölderlina na temat Patmos ${ }^{30}$. Interesującym tropem jest struktura prozodyjna wierszy, która w przypadku każdego z trzech poetów wykazuje wyraźne odniesienia do antyku, nawet jeśli zewnętrzny typograficzny wygląd przede wszystkim późnych wierszy Miłosza zupełnie odbiega od przeważnie krótkich wersów Hölderlina i Bobrowskiego. Wspólny wszystkim trzem poetom jest twórczy dystans wobec systemów wierszowania przyjętych w danym okresie i w danej kulturze literackiej. Ponadto geograficzne sąsiedztwo, dość bliskie w wypadku Miłosza i Bobrowskiego oraz bynajmniej nie wspólne, a jednak paralelne doświadczenia katastrof XX w., nie są tu bez znaczenia. Niewykluczone, że znawcy archiwów odkryją kiedyś, że Bobrowski wiedział o istnieniu Czesława Miłosza, a ten - Bobrowskiego.

${ }^{28}$ Zob. komentarz J. Schmidta, w: Hölderlin I, op. cit., 602. Miłosz mógł znać ten łaciński utwór. Tekst Panegyricus Messallae na <http://www.hsaugsburg.de/ harsch/Chronologia/Lsante01/Tibullus/ tib_cor4.html\#1>.

${ }^{29}$ Cz. Miłosz, Wiersze..., op. cit., s. 644-646 (i następne wywody prozą).

${ }^{30}$ Hölderlin, op. cit., s. 350-360. 